OPEN ACCESS

Edited by:

Bahar Razavi,

University of Kiel, Germany

Reviewed by:

Thiago Gumiere

Laval University, Canada

Amin Soltangheisi,

Lancaster University, United Kingdom

${ }^{*}$ Correspondence:

Laura Bardi

laura.bardi@crea.gov.it

Specialty section:

This article was submitted to Plant-Soil Interactions, a section of the journal Frontiers in Agronomy

Received: 27 February 2020 Accepted: 14 April 2020 Published: 15 May 2020

Citation:

Bardi L (2020) Early Kiwifruit Decline: A Soil-Borne Disease Syndrome or a Climate Change Effect on Plant-Soil

Relations? Front. Agron. 2:3.

doi: $10.3389 /$ fagro.2020.00003

\section{Early Kiwifruit Decline: A Soil-Borne Disease Syndrome or a Climate Change Effect on Plant-Soil Relations?}

\author{
Laura Bardi* \\ Research Centre for Engineering and Agro-Food Processing, CREA Council for Agricultural Research and Economics, Turin, \\ Italy
}

Early kiwifruit decline is a physiological disorder reported for the first time in New Zealand following a cyclone that caused a heavy and prolonged flooding of kiwifruit orchards. Following studies on kiwifruit vine physiology and anatomy demonstrated that this plant has a significant water demand but is also extremely sensible to root waterlogging and soil anoxic conditions. Pathogenic microorganisms were sometimes identified in soil and root samples of declining plants, but they were not considered the primary cause of kiwifruit decline, and their presence in roots was considered a consequence of waterlogging and plant weakening. Agronomic practices have been developed and adopted to deliver water in amounts adequate to plant needs, but avoiding excess and stagnation in the soil, and to improve soil aeration. However, in recent years, early decline has seen worldwide spread, affecting even orchards in which waterlogging is prevented or is only occasionally caused by intense local rainfall. A global overview of the knowledge on botanical, physiological, and ecological traits of kiwifruit, along with the examination of phenomena concomitant to early decline appearance, can help to identify the causes and the possible actions to prevent its occurrence. Some assumptions and possible solution attempts are proposed.

Keywords: kiwifruit, physiological disorder, soil, roots, abiotic stress, climate change

\section{INTRODUCTION}

The kiwifruit, a spontaneous plant native to China whose fruits were widely harvested from the wild, was introduced in New Zealand, Europe, and America at the beginning of twentieth century, and its cultivation rapidly spread through temperate regions in the second half of the century. Nowadays it is a very important fruit crop in several countries beyond China, such as Italy, New Zealand, Chile, and Greece (Ferguson, 2016). At present, nearly 3 million tons of kiwifruits are estimated to be produced annually in the world (Guroo et al., 2017).

Kiwifruits are vines, and they are usually cultivated in canopies. Since the beginning of their cultivation spread, physiological disorder symptoms were observed in orchards, including leaf epinasty, chlorosis, desiccation and abscission, growth stop, and reduced fruit production; these were associated with anomalous root morphology and anatomy, disappearance of fibrous roots, and rotting of structural roots (Savé and Serrano, 1986; Xyloyannis et al., 1986; Smith et al., 1989; Reid et al., 1991). These symptoms usually appeared mid-summer; a progressive worsening 
was usually observed in following years, which could lead to the complete harvest loss and to plant death. In March 1988, New Zealand, the cyclone Bola caused a heavy and prolonged flooding of kiwifruit orchards after which a widespread early vine decline was reported; reduced performance of the same vines observed in the following season was considered a long-time consequence of the waterlogging event (Reid et al., 1992). Progressively, the seriousness and the diffusion of this disorder in kiwifruit orchards all over the world has attracted more attention and induced people to better take into consideration the physiological traits of the plant for crop management. The effect of flooding, due to either meteoric events or excessive or wrong watering management, was examined in view of the high sensitivity of kiwifruit roots to low oxygen availability (Savé and Serrano, 1986; Smith et al., 1989, 1990; Reid et al., 1991, 1992). The effect of other soil-borne abiotic stress factors (structure and texture, elevation, and transmission properties Reid et al., 1991, nutrient availability, including organic matter, heavy metal content, xenobiotics phytotoxicity, water availability, and temperature (Xyloyannis et al., 1986; Smith et al., 1989), as well as management practices, e.g., overpruning and overcropping (Black et al., 2012), or soilborne pests (pathogenic microorganisms) (Reid et al., 1991; Tacconi et al., 2014, 2015) on the occurrence of the decline symptoms has also been assessed. It was stated that each of these factors, when examined alone, cannot be considered as the cause of early kiwifruit decline (Sorrenti et al., 2016; Tacconi et al., 2019); moreover, most of them were in turn related to soil anoxia or excess water content (Savé and Serrano, 1986; Wilde and Hughes, 1987; Smith et al., 1989; Reid et al., 1991; Sorrenti et al., 2016). As waterlogging was ascertained to be the most common factor related to the appearance of kiwifruit decline, suitable crop management systems aiming to improve root aeration, such as soil trunking and convexing, soil conditioning with organic fertilizers, and localized watering with specific amounts of water delivered daily on the basis of crop consumption to maintain the soil field capacity constant, were proposed; however, the onset of this disease was not hampered. In 2012 the physiological disorder symptoms appeared in some orchards located in Italian northern regions, mainly in lowland soils (Montanaro et al., 2014; Tacconi et al., 2014; Tosi et al., 2015; Sorrenti et al., 2016; Nari and Vittone, 2017). Also in this case, the practices adopted to improve root aeration through changes in soil chemico-physical properties were not sufficient to prevent the worsening of the symptoms occurring in both young and adult orchards; plants that do not totally collapse within 12 months usually die the year after (Spigaglia et al., 2020). Moreover, early kiwifruit decline rapidly spread across northern and central Italy, in both old and new plantings, and, consequently, a steady trend of reduction of the land area for kiwifruit production followed. In 2018, 12.6\% of the Italian kiwifruit orchards were dead and uprooted, but the severity of the damage is greatest in Northern regions, with $70 \%$ of orchards uprooted in Veneto and $28 \%$ in Piedmont, and this trend is still in progress (Tacconi et al., 2019; Spigaglia et al., 2020).

Since 2010, 2 years before the onset of early kiwifruit decline, the kiwifruit orchards in Italy experienced a dramatic epidemy of a bacterial disease caused by Pseudomonas syringae pv actinidiae
(PSA). This pathogen was recorded for the first time in 1994, but it remained unnoticed for more than 15 years; then, it emerged becoming rapidly pandemic and causing severe damages, as a result of which many orchards were uprooted (Scortichini et al., 2012). As a consequence, agronomical techniques and control strategies were reorganized in order to reduce the incidence and severity of the disease and the risk of further spread. The control of the disease has reached in many areas of cultivation worldwide a rather satisfactory level despite the endemic presence of the pathogen in the orchards (Scortichini, 2018). The symptoms induced by PSA are significantly different from those of early vine decline, and PSA cannot be considered a direct cause of early decline; however, as PSA is still almost always present, a sort of coexistence with the disease is evident in kiwifruit orchards (Scortichini, 2018); a resulting general plant weakening can thus be considered a possible predisposition to other diseases.

According to the evidence presented, the early kiwifruit decline is still an unsolved problem. Each of the possible factors examined till now, even if correlated with the decline onset, cannot be considered as the sole cause, and its control does not prevent the decline onset or worsening till plant death. The hypothesis that this disorder can arise following the gathering of multiple factors is currently accepted; however, reliable remedies or preventive measures to overcome its effects are still not available.

Over the last few years, particularly in the Mediterranean area, the weather conditions have shown a general rise in temperature, particularly during summer, and long drought periods interrupted by heavy rainfall, according to global change (JMA, 2019). Taking into consideration the peculiarities of kiwifruit vine anatomy and physiology, a comprehensive examination of the changes that have arisen in both environmental factors and kiwifruit crop management techniques could help in finding solutions to this problem that seriously affects economic sustainability of several rural areas where kiwifruit is an important crop.

\section{KIWIFRUIT: BOTANICAL AND ECOLOGICAL TRAITS}

The commercial kiwifruits belong to the genus Actinidia: Actinidia chinensis var. deliciosa (the green-fleshed kiwifruit), Actinidia chinensis var. chinensis (the yellow-fleshed), and the kiwiberry Actinidia arguta. The genus Actinidia has been widely described, and its botanical, physiological, and anatomical traits can be found in exhaustive reviews (Ferguson, 1984, 2016; Lemon and Considine, 1993; Testolin et al., 2016; Akram, 2018). In this work, some aspects helpful to understanding kiwifruit physiological disorders are evidenced.

\section{Kiwifruit Ecology}

The natural habitats in which Actinidia species spontaneously grow are hills or mountains of eastern and southern Asia. They are perennial, deciduous plants with large leaves that climb with long weak shoots over trees. Kiwifruits are usually found on the banks of steep gullies, near springs, in dense forests, or in scrub 
vegetation with high relative humidity maintained throughout the year, while they are rarely found on hill tops or in places where moisture is low; they grow under the tree canopy, shaded from excessive sunlight. In the wild, these plants are exposed to large variations in temperature between day and night and between summer and winter (up to $50^{\circ} \mathrm{C}$ difference). Dormancy makes vine cold resistant in winter, even when top layers of soil freeze (Ferguson, 1984). In general, A. chinensis var. deliciosa prefers colder climate and higher altitudes, while A. chinensis var. chinensis occurs in warmer lowland areas (Ferguson, 2016).

It follows that the cultivated kiwifruit requires high humidity and rainfall that is distributed well throughout the growing season, cold winters, long frost-free growing periods, moderate intensity of sunlight, and shelter from wind (Ferguson, 1984).

\section{Kiwifruit Root System}

The anatomy and histochemistry of the root system of $A$. deliciosa var. deliciosa has been extensively described by Lemon and Considine (1993); however, it is crucial to summarize their findings in view of the implications with the kiwifruit early decline.

The greater part of the root system (about 95\% of total length) is formed by fibrous roots, which occur as bunches arising from structural roots, and exhibit a small and uniform diameter. Most fibrous roots persist for more than one season, going through cycles of dormancy and suberization of the root tip followed by reactivation or death. Structural roots usually form from the older portion of pioneer roots, but some fibrous roots can also develop into structural roots. New white roots arise from older fibrous roots or from large structural roots. Root hairs were not observed on roots collected from the field, though plants grown in solution culture developed conspicuous root hairs.

The anatomical development of kiwifruit roots is characterized by some peculiar traits that are different from other plants (Figure 1). Structural and fibrous roots retain a cortex, also when roots grow with extensive secondary thickening. The cork is a relatively small component of the structural root and the bulk of the tissue is vascular in origin, as in other plant species. The endodermis is retained and continues to divide periclinally to accommodate the increase in circumference with growth. The pericycle, endodermis, cortex, and cork form a tannin-rich, thin outer protective layer on the root surface. Phelloderm is initiated by hypodermal cells within the cortex and not by the pericycle; this phellogen produces new cells centrifugally only. The periderm development seems to closely resemble stem periderm formation.

Deposition of suberin forms casparian bands in endodermal cells and lamellae on the inside walls of cork and endodermal cells, while hypodermal casparian bands are not formed: this implies that kiwifruit roots do not possess an exodermis. The retaining of cortex even in thick roots may be due to a symplastic continuity between the cortex and vascular tissue, which suggests that also secondary thickened roots may be capable of absorption.

The root tips of young roots can be suberized but may resume growth by regeneration from their suberized tips. The long life and slower turnover of fibrous roots of kiwifruit

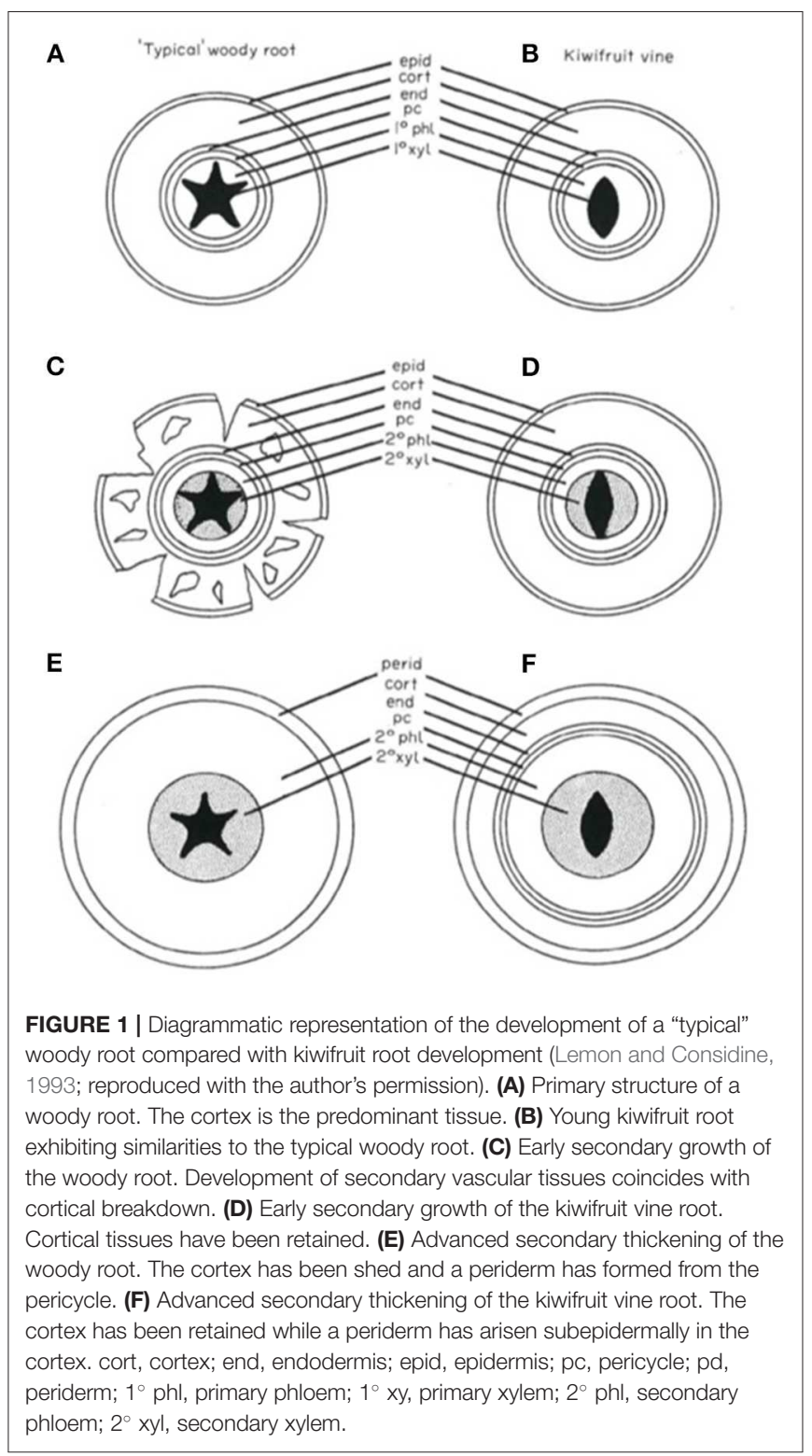

in comparison to other species could also be explained by this characteristic. This strategy is similar to that adopted by grapevine to tolerate unfavorable soil conditions avoiding plant desiccation. Lemon and Considine (1993) suggested a threestage development process for roots in kiwifruit: (a) primary development of white roots; (b) pre-secondary development of fibrous roots through the formation of a xylem cylinder without increase in root diameter; and (c) secondary thickening (structural roots) through the further development of secondary tissues with increase in root diameter, though the cortex and endodermis persist while suberization on periderm is completed. A failure in the activation of the secondary cambium, initiation of a phellogen in the hypodermis, and reactivation of cell division in the endodermis could lead to rootlet death, as occurs in other plant species to control the fine root turnover. 
Secondary xylem is composed of both tracheids and vessel elements. Secondary phloem is made of sieve tube elements with companion cells, but its main component is parenchyma, with large idioblasts containing mucilage or raphides. Following secondary growth, roots develop radial parenchyma rays through the xylem core and the phloem; phloem fibers with thick secondary walls develop in cell clusters. Cortex and phloem cell walls are cellulosic only; vessel, tracheids, and fiber cell walls are lignified, whilst epidermal and endodermal cells are not. Starch grains accumulate progressively, initially in the cortex, while large starch grains in old roots are mainly located in phloem parenchyma; fewer grains also occur in xylem ray cells.

\section{Root Symptoms and Possible Causes Explored in Kiwifruit Decline}

In kiwifruit orchards showing symptoms of decline, the root system appears strongly reduced: in particular, a significant decrease of fibrous roots is observed. Structural roots show a brown discoloration of the stele, fibrous roots show cortical decay, and the cortical tissue loses rigidity and detaches from central stele (Reid et al., 1991; Tosi et al., 2015). Xylematic vessels are reduced in number and diameter and sometimes appear obstructed; the phloematic tissue appear destructured and reduced in thickness (Sorrenti et al., 2016). The soil surrounding the root surface is frequently mucilaginous.

The roots characteristics observed on kiwifruit plants after waterlogging events (Smith et al., 1990; Reid et al., 1991) strongly correspond to symptoms usually observed in roots of plants with symptoms of the early decline. In a comprehensive study on the effect of roots oxygen depletion, due to transient waterlogging, on plant physiology and recovery, Smith et al. (1990) observed that the decreasing concentration of oxygen in the root zone had a rapid and strong effect on the growth of the vine. The waterlogged roots lost dry weight due to physical loss of root tissue as well as lack of growth. The cortex detached from the central stele through the dissolution of an entire layer of cortical cells surrounding the endodermis, which, in the control vines, were filled with starch; the cortical cells were generally distorted with much of the intercellular material missing. No evidence of growth recovery was observed once aeration was restored to the root system, except for the appearance of new roots at the base of the stem of vines that had been waterlogged for $<5$ days; the quantity of new roots was inversely related to the time of waterlogging. The rate of root death and the associated damage to the leaves was proposed as the cause of limited ability of kiwifruit vines to resume growth once oxygen supply to the roots was restored (Smith et al., 1990). A study on vine performance carried out during the season following flooding and alluvium deposition evidenced great damage to yield and casted doubts on the convenience to save vines showing early decline symptoms following waterlogging events (Reid et al., 1992).

Pathogenic microorganisms (Phytophtora, Pythium, Cylindrocarpon, Fusarium, Pyrenochaeta, and Erwinia) were sometimes identified in soil and root samples of declining plants (Reid et al., 1991). Root diseases caused by Phytophtora spp. are intensified by waterlogging because zoospore formation and dispersal are enhanced, the roots exude more chemical attractors for the zoospores, and the roots themselves are predisposed to infection (Reid et al., 1991). However, these infections were not considered the primary cause of vine decline, nor did they have a significant effect on subsequent vine performance resulting from fungicide applications to either stressed or healthy vines (Reid et al., 1991). Their presence in roots can thus be considered a consequence, rather than a cause, of kiwifruit decline due to oxygen depletion. Similar outcomes were recently the results of new studies that have been conducted following the appearance of early kiwifruit decline in the Mediterranean area on kiwifruit soil and roots, looking for possible pathogenic microorganisms involvement (Montanaro et al., 2014; Tacconi et al., 2015, 2019; Sorrenti et al., 2016).

A recent study pointed to soil bacteria having a possible role in kiwifruit decline; it showed the direct involvement of these bacteria in kiwifruit decline of Clostridia, which are not usually considered phytopathogenic microorganisms; however, also in this case, it was observed that the growth of Clostridia, which are anaerobic bacteria, is possible in kiwifruit roots due to anoxic soil conditions (Spigaglia et al., 2020). This study also evidenced the importance of paying attention to the microbiological quality of water used for irrigation; however, also the microbiological quality of organic fertilizers should be taken into consideration: for example, manure and compost can be important sources of Clostridia (Dharmasena and Jiang, 2018). Moreover, even if organic fertilizers are important to improve soil structure and water availability, if they are too rich in active microbial populations, they can compete with roots for oxygen consumption and worsen the roots anoxic state (Bardi and Malusà, 2012).

A disease similar to early kiwifruit decline was described for jarrah (Eucaliptus marginata) (Davison, 2014). In the 1940s, the sudden death of groups of jarrah trees was described in southwestern Australia. It occurred on poorly drained sites following exceptionally heavy rainfall. In the 1960s, these sites were shown to be infested by Phytophthora cinnamomi, and jarrah deaths were attributed to it, even though it was only isolated from 5\% of sampled trees. Jarrah trees die from severe water deficiency, indicating problems with water conduction through roots. Jarrah transpires vigorously during summer, accessing water at depth on sites with deep soil but being more dependent on water stored internally in large xylem vessels when root systems are shallower. Following waterlogging, both the conductivity and potential water storage of xylem vessels were reduced; the root systems were altered with vertical roots not being numerous or well-developed, being often short and fanged. As P. cinnamomi is unlikely to cause water deficiency because it causes necrotic lesions in the phloem but not in the sapwood, tree decline was attributed to insufficient internal water reserves for summer survival (Davison, 2014).

The root tissues damage of kiwifruit plants showing the early decline symptoms has been observed even in absence of waterlogging in several orchards in Northern Italy (Tacconi et al., 2019). Therefore, other causes, besides waterlogging, inducing oxygen depletion in soil, and the progressive loss and death of roots should be considered. 


\section{DISCUSSION}

It is widely accepted that the main cause of early kiwifruit decline is an insufficient oxygen availability to roots. So far, waterlogging has been considered as the main cause of soil hypoxic conditions; however, the crop management techniques planned to improve soil aeration and avoid waterlogging have not been sufficient to prevent vine decline onset. Nevertheless, one factor that could contemporarily reduce oxygen diffusion in soil and kiwifruit root growth has not yet been sufficiently considered: high soil temperature.

The kiwifruit root system is remarkably sensible to high soil temperatures: at above $25^{\circ} \mathrm{C}$, root growth decreases (Smith et al., $1989,1990)$. The peak of the growth of fibrous roots does not occur until mid-summer, when the relative growth rate of the shoots and fruits have fallen to low levels, because the root is the weakest sink in the competition within the vine for available assimilates (Smith et al., 1989). Therefore, the phenological phase of root growth occurs just when the risk of temperature-induced inhibition is highest. Additionally, oxygen availability in soil is reduced by high temperatures, introducing a further root stress factor (Smith et al., 1989). It follows that the root growth and functionality could be impaired just when, due to high temperature in summer, the transpiration demand from leaves is highest for homeostasis.

A general rise in temperature, particularly during summer, has been recorded in Northern Italy over the last years as an effect of climate change (RAN, 2019). Soil temperatures can reach very high values, especially where the soil is not shaded by canopies (Horton, 1989). The combined effect of high soil temperature and reduced oxygen availability could thus explain the occurrence of the early decline symptoms in new plantations, or in orchards with sandy soils, not having experienced excess water events. The modification of the training system to reduce the woody volume of the plant and enhance the air circulation within the canopy aimed to reduce the risk of PSA development (Scortichini, 2018) could expose the soil to a major risk of temperature increase due to lower shading. High summer temperature also causes a major shift in photosynthate partitioning toward vegetative growth, dramatically reducing fruit carbohydrate accumulation; growth and flowering are also severely reduced in the following season (Richardson et al., 2004).

Metabolism modification of root tissues could also be related to the early kiwifruit decline. Meristems are the tissues most sensitive to oxygen depletion, being characterized by high cell density with high oxygen-demanding metabolic activity and limited oxygen entry. Therefore, the root tips are often the first part of the root system to be damaged (Smith et al., 1990; Bailey-Serres and Voesenek, 2008). This could explain the stunted growth of new fibrous roots, typical symptoms of declining kiwifruit plants, and the lack of reactivation of suberized root tips, which ensures persistence for more than 1 year of fibrous roots particular to kiwifruit plants. Furthermore, the fermentative metabolism induced by lack of oxygen can result in cell death when starch reserves are exhausted (Bailey-Serres and Voesenek, 2008). The depletion of starch, particularly in phloematic tissue, and destruction of cell layers surrounding or covering meristems is observed in the roots of kiwifruit showing decline symptoms (Smith et al., 1990). Moreover, the failure in the activation of secondary cambium, initiation of phellogen, and reactivation of cell division in the endodermis could lead to rootlet death (Lemon and Considine, 1993). Low oxygen could also induce the loss of rigidity of cortical tissue observed in the roots of declining plants due to induced cellulase, pectinase, and xylanase enzyme activity (Smith et al., 1990; Bailey-Serres and Voesenek, 2008). Damaged root tissues can be more easily colonized by soil microorganisms that usually are not pathogenic (Spigaglia et al., 2020).

Soil structure is basic in determining the water and oxygen availability of roots (Vervoort and Cattle, 2003; Chertkov, 2013). Agronomic practices, such as inter-row soil management, different tillage systems, and frequent agricultural vehicle passages, which induce soil compaction, and irrigation systems, such as flooding, that induce runoff, sediment losses, and destruction of soil structure, can have a major role in worsening the root environment (Corti et al., 2011; Destain et al., 2014; Montanaro et al., 2014; Capello et al., 2017). Moreover, reducing conditions in the rhizosphere are changing nutrients availability that can significantly modify the nutritional status of the plant and increase its exposition to phytotoxicity effects of micronutrients (Nilsen and Orcutt, 1996). The addition of organic matter is a common practice recommended to restoring soil structure, but it has been recently demonstrated that the addition of organic matter in soil can influence the soil moisture capacity differently, depending on soil and climate conditions, and that the real available soil water capacity is not significantly increased by soil organic matter (Bonfante et al., 2020). Moreover, the consequent stimulation of soil microbial activities, in particular if temperature is high, could further contribute to create anoxic conditions (Bardi and Malusà, 2012). A long-term crop management strategy that is disrespectful of soil quality could then have irreparable consequences.

All the modifications of soil physico-chemical conditions mentioned above have been associated with a progressive deterioration of soil quality over time under normal management practices applied in kiwifruit orchards. These changes, associated with climatic change observed over recent years and to peculiar physiological and anatomical traits of kiwifruit plants, could have induced the emergence of early kiwifruit decline in vast territories, even where it was never observed before.

In order to prevent the disappearance of kiwifruit from territories where this crop has developed a strong value chain, under a climate change scenario, it is thus necessary to take into account the environmental conditions required by this plant, particularly soil oxygen availability, protection from very high temperatures, shading, and humidity. Overtree microsprinkler irrigation could be a practice with which to facilitate leaf homeostasis, protecting them from excessive temperatures, delivering water and, possibly, nutrients during hot summer days, when the growth of PSA, which could be promoted by this practice, is strongly inhibited by high temperature (Scortichini et al., 2012). Over-head irrigation has also been proposed to protect kiwifruit orchards during frost events that promote an increase in the aggressiveness of PSA; this technique did not incite significant multiplication of PSA, and the risk for 
the possible subsequent spread of the pathogen within the orchard can be avoided by watering the plant during morning, thus allowing the foliage to dry (Scortichini, 2018). So, the same technique could be used during different seasons for different purposes.

Soil shading and furrow irrigation could help to prevent excessive soil temperatures and favor root development on a wider soil volume. The selection of varieties or rootstocks suited to the local environmental conditions should also be considered to reduce the risk of vine decline occurrence. The role of any crop management practice, including the use of phytoregulators, such as Forchlorfenuron, proposed to reduce PSA disease incidence and severity (Gould et al., 2015; Donati et al., 2019) and to increase kiwifruit size (Patterson et al., 1993),

\section{REFERENCES}

Akram, M. (2018). The physiology and biochemistry of kiwifruit (Actinidia deliciosa). Biol. Forum Int. J. 10, 129-133.

Bailey-Serres, J., and Voesenek, L. A. C. J. (2008). Flooding stress: acclimations and genetic diversity. Annu. Rev. Plant Biol. 59, 313-339. doi: 10.1146/annurev.arplant.59.032607.092752

Bardi, L., and Malusà, E. (2012). "Drought and nutritional stresses in plants: alleviating role of rhizospheric microorganisms," in Abiotic Stress: New Research, eds N. Haryana and S. Punj (Hauppauge, NY: Nova Science Publishers, Inc.), 1-56.

Black, M. Z., Patterson, K. J., Gould, K. S., and Clearwater, M. J. (2012). Physiological responses of kiwifruit vines (Actinidia chinensis Planch. var. chinensis) to trunk girdling and root pruning. N. Zeal. J. Crop Hortic. Sci. 40, 31-41. doi: 10.1080/01140671.2011.603343

Bonfante, A., Basile, A., and Boum, J. (2020). Exploring the effect of varying soil organic matter contents on current and future moisture supply capacities of six Italian soils. Geoderma 361:114079. doi: 10.1016/j.geoderma.2019.114079

Capello, G., Biddoccu, M., Ferraris, S., Pitacco, A., and Cavallo, E. (2017). Year-round variability of field-saturated hydraulic conductivity and runoff in tilled and grassed vineyards. Chem. Eng. Trans. 58, 739-744. doi: 10.3303/CET1758124

Chertkov, V. Y. (2013). Shrinkage anisotropy characteristics from soil structure and initial sample/layer size. Geoderma 201, 1-8. doi: 10.1016/j.geoderma.2013.02.009

Corti, G., Cavallo, E., Cocco, S., Biddoccu, M., Brecciaroli, G., and Agnelli, A. (2011). "Evaluation of erosion intensity and some of its consequences in vineyards from two hilly environments under a mediterranean type of climate in Italy," Soil Erosion Issues in Agriculture, eds D. Godone and S. Stanchi (InTech), 334. doi: 10.5772/25130

Davison, E. M. (2014). Resolving confusions about jarrah dieback - don't forget the plants. Austral. Plant Pathol. 43, 691-701. doi: 10.1007/s13313-014-0302-y

Destain, M. F., Roisin, C., and Mercatoris, B. C. N. (2014). "Soil compaction resulting from different soil tillage systems," in ASABE and CSBE/SCGAB Annual International Meeting (Montreal, QC, Canada).

Dharmasena, M., and Jiang, X. (2018). Isolation of toxigenic Clostridium difficile from animal manure and composts being used as biological soil amendments. Appl. Environ. Microbiol. 84:e00738-18. doi: 10.1128/AEM.00738-18

Donati, I., Mauri, S., Cellini, A., Buriani, G., Fiorentini, L., Costa, G., et al. (2019). Influence of cultural practices on the incidence and severity of kiwifruit bacterial canker. Acta Hortic. 1243, 59-64. doi: 10.17660/ActaHortic.2019.1243.10

Ferguson, A. R. (1984). Kiwifruit: a botanical review. Hort. Rew. 6, 1-64. doi: 10.1002/9781118060797.ch1

Ferguson, A. R. (2016). "World economic importance", in The Kiwifruit Genome, Compendium of Plant Genomes, eds R. Testolin, H. W. Huang, and A. R. Ferguson (Springer International Publishing Switzerland), 37-42. which could alter the optimal root/shoot growth balance, should also be investigated.

\section{AUTHOR CONTRIBUTIONS}

The author confirms being the sole contributor of this work and has approved it for publication.

\section{ACKNOWLEDGMENTS}

I acknowledge Chiara Morone and Luca Nari for the wealth of information and for readiness to share their hands-on experience and passionate work.

Gould, E. M., Black, M. Z., Clark, G., Tanner, D. J., and Benge, J. (2015). Tools for managing the kiwifruit bacterial canker disease Pseudomonas syringae pv actinidiae (Psa). Acta Hortic. 1105, 39-46. doi: 10.17660/ActaHortic.2015.1105.6

Guroo, I., Wani, S. A., Wani, S. M., Ahmad, M., Mir, S. A., and Masoodi, F. A. (2017). A review of production and processing of kiwifruit. J. Food Process. Technol. 8:699. doi: 10.4172/2157-7110.1000699

Horton, R. (1989). Canopy shading effects on soil heat and water flow. Soil Sci. Soc. 53, 669-679. doi: 10.2136/sssaj1989.03615995005300030004x

JMA (2019). Climate Change Monitoring Report. Japan Meteorological Agency, 92. Available online at:http://www.jma.go.jp/jma/en/NMHS/indexe_ccmr.html

Lemon, C. W., and Considine, J. A. (1993). Anatomy and histochemistry of the root system of the kiwifruit vine, Actinidia deliciosa var. deliciosa. Ann. Botany 71, 117-129. doi: 10.1006/anbo.1993.1015

Montanaro, G., Dichio, B., Mininni, A. N., and Xiloyannis, C. (2014). Actinidia irrigata a scorrimento: pratica da abbandonare. Linformatore Agrario 2, 73-76. Available online at: http://hdl.handle.net/11563/67691

Nari, L., and Vittone, G. (2017). La moria dell'actinidia: sintomi, cause e possibili rimedi. Linformatore Agrario 16, 2-5. Available online at: http://www. ediagroup.it/BDO/BDO_popupAbstract.asp?D=129632

Nilsen, E. T., and Orcutt, D. M. (1996). The Physiology of Plants Under Stress. New York, NY: John Wiley \& Sons, INC.

Patterson, K. J., Mason, K. A., and Gould, K. S. (1993). Effects of CPPU (N-(2-chloro-4-pyridyl)-N'-phenylurea) on fruit growth, maturity, and storage quality of kiwifruit. N. Zeal. J. Crop Hortic. Sci. 21, 253-261. doi: 10.1080/01140671.1993.9513777

RAN (Rete Agrometeorologica Nazionale)-MIPAAF. (2019). Available online at: https://www.politicheagricole.it/flex/FixedPages/Common/miepfy200_ reteAgrometeorologica.php/L/IT.

Reid, J. B., Tate, K. G., and Brown, N. S. (1992). Effects of flooding and alluvium deposition on kiwifruit (Actinidia deliciosa). N. Zeal. J. Crop Hortic. Sci. 20, 283-288, doi: 10.1080/01140671.1992.10421769

Reid, J. B., Tate, K. G., Brown, N. S., and Cheah, L. H. (1991). Effects of flooding and alluvium deposition on kiwifruit (Actinidia deliciosa): 1. Early vine decline. N. Zeal. J. Crop Hortic. Sci. 19, 247-257. doi: 10.1080/01140671.1991.10421808

Richardson, A. C., Marsh, K. B., Boldingh, H. L., Pickering, A. H., Bulley, S. M., Frearson, N. J., et al. (2004). High growing temperatures reduce fruit carbohydrate and vitamin C in kiwifruit. Plant Cell Environ. 27, 423-435. doi: 10.1111/j.1365-3040.2003.01161.x

Savé, R., and Serrano, L. (1986). Some physiological and growth responses of kiwi fruit (Actinidia chinensis) to flooding. Physiol. Plant. 66, 75-78. doi: 10.1111/j.1399-3054.1986.tb01236.x

Scortichini, M. (2018). Aspects still to solve for the management of kiwifruit bacterial canker caused by Pseudomonas syringae pv. actinidiae biovar 3. Eur. J. Hortic. Sci. 83, 205-211. doi: 10.17660/eJHS.2018/83.4.1

Scortichini, M., Marcelletti, S., Ferrante, P., Petriccione, M., and And Firrao, G. (2012). Pseudomonas syringae pv. actinidiae: a re-emerging, 
multi-faceted, pandemic pathogen. Mol. Plant Pathol. 13, 631-640. doi: 10.1111/j.1364-3703.2012.00788.x

Smith, G. S., Buwalda, J. G., Green, T. G. A., and Clark, C. J. (1989). Effect of oxygen supply and temperature at the root on the physiology of kiwifruit vines. New Phytol. 113, 431-437. doi: 10.1111/j.1469-8137.1989.tb00354.x

Smith, G. S., Judd, M. J., Miller, S. A., and Buwalda, J. G. (1990). Recovery of kiwifruit vines from transient waterlogging of the root system. New Phytol. 115, 325-333. doi: 10.1111/j.1469-8137.1990.tb0 00459.x

Sorrenti, G., Toselli, M., Reggidori, G., Spinelli, F., Tosi, L., Giacopini, A., et al. (2016). Implicazioni della gestione idrica nella "moria del kiwi" del veronese. Frutticoltura 3, 2-7. Available online at: https://www.researchgate. net/publication/297757814

Spigaglia, P., Barbanti, F., Marocchi, F., Mastroleo, M., Baretta, M., Ferrante, P., et al. (2020). Clostridium bifermentans and C. subterminale are associated with kiwifruit vine decline, known as moria, in Italy. Plant Pathol. 69, 765-774. doi: $10.1111 /$ ppa.13161

Tacconi, G., Giacopini, A., Vittone, G., Nari, L., Spadaro, D., Savian, F., et al. (2019). Moria del kiwi: situazione disastrosa al nord, preoccupante nel resto d'Italia. Periodico Sci. Monotematico 14, 32-37.

Tacconi, G., Paltrinieri, S., Mejia, J. F., Fuentealba, S. P., Bertaccini, A., Tosi, L., et al. (2015). Vine decline in kiwifruit: climate change and effect on waterlogging and Phytophthora in North Italy. Acta Hortic. 1096, 93-97. doi: 10.17660/ActaHortic.2015.01096.7

Tacconi, G., Tosi, L., Giacopini, A., Bertaccini, A., Mazzucchi, U., Favaron, F., et al. (2014). "Vine decline in kiwifruit: climate change and effect on waterlogging and Phythopthora in North Italy," in The 8th International Symposium on Kiwifruit - China. doi: 10.17660/ActaHortic.2015.1096.7

Testolin, R., Huang, H. W., and Ferguson, A. R. (2016). The Kiwifruit Genome. Springer International Publishing Switzerland. doi: 10.1007/978-3-319-32274-2

Tosi, L., Giacopini, A., and Tacconi, G. (2015). La moria del kiwi, situazione e prospettive. L'Informatore Agrario 44, 67-70. Available online at: http://www. ediagroup.it/BDO/BDO_popupAbstract.asp?D=123393

Vervoort, R. W., and Cattle, S. R. (2003). Linking hydraulic conductivity and tortuosity parameters to pore space geometry and pore-size distribution. $J$. Hydrol. 272, 36-49. doi: 10.1016/S0022-1694(02)00253-6

Wilde, R. H., and Hughes, K. A. (1987). Horticultural development: money down the drain? Orchardist N. Zeal. 60, 54-56.

Xyloyannis, C., Natali, S., Fregni, G., and Botrini, L. (1986). Influenza dell'umidità relativa sulla traspirazione dell'actinidia e dell'olivo e sul disseccamento fogliare dell'actinidia. Rivista Frutticoltura 5, 43-47.

Conflict of Interest: The author declares that the research was conducted in the absence of any commercial or financial relationships that could be construed as a potential conflict of interest.

Copyright (c) 2020 Bardi. This is an open-access article distributed under the terms of the Creative Commons Attribution License (CC BY). The use, distribution or reproduction in other forums is permitted, provided the original author(s) and the copyright owner(s) are credited and that the original publication in this journal is cited, in accordance with accepted academic practice. No use, distribution or reproduction is permitted which does not comply with these terms. 